\title{
Elevsamtalens muligheter og begrensninger i lys av eleverfaringer
}

\section{Sammendrag}

Artikkelen drøfter elevsamtalens muligheter og begrensninger med basis i elevers erfaringer i videregående skole. Hva er gode elevsamtaler, og hva kjennetegner mindre gode samtaler mellom lærer og elev, slik elever opplever det? Elevenes beretninger blir presentert i erfaringsnær, tematisk form. Sentrale kjennetegn ved det empiriske dialogbegrepet utgjør en ramme for forståelse av erfaringene. Resultatene indikerer at elevsamtalen gir mulighet til å skape trygghet for eleven, utvikle gode elev-lærer-relasjoner og styrke elevens motivasjon og læring. Samtidig avdekkes vesentlige svakheter og et betydelig forbedringspotensial når det gjelder å utnytte elevsamtalenes muligheter.

Emneord: elevsamtale, elev-lærer-dialog, elev-lærer-relasjon, underveisvurdering, formativ vurdering, vurdering for læring

\section{Abstract}

The article discusses possibilities and problems of individual student-teacher dialogues in upper secondary schools, based on student experiences. What are the characteristics of positive and negative dialogues, respectively, as experienced by students? The findings are presented as experience-near themes. Basic characteristics of an empirical concept of 'dialogue' are used as a framework for understanding the experiences. The findings indicate that student-teacher dialogues can help students feel safe, develop positive student-teacher relationships and strengthen the students' motivation and learning. However, a range of problems and weaknesses are also found. It is concluded therefore, that there is a considerable potential for improving pupil-teacher dialogues.

Keywords: student-teacher dialogues; student-teacher-relationship; formative assessment; assessment practices 


\section{Innledning}

Det foregår mange slags samtaler mellom lærer og elev i skolen, fra de helt spontane og hverdagslige til de planlagte, institusjonaliserte samtalene som oftest betegnes som «elevsamtale» eller «utviklingssamtale». Eleven har rett til en samtale med kontaktlæreren minst en gang hvert halvår om sin utvikling i forhold til kompetansemålene i fagene, fastsatt i Forskrift til opplæringslova, $\S 3.11$ (Kunnskapsdepartementet 2006). Samtalen skal være et ledd i underveisvurdering. I tillegg har eleven rett til jevnlig dialog med kontaktlæreren om sin utvikling i lys av skolens formål m.m. (Forskrift til opplæringslova § 3-8). Dette dreier seg blant annet om personlig og sosial utvikling. I praksis er det glidende overganger mellom de to typene av samtaler (Limstrand 2006; Sjøbakken 2012). I videregående skole og til dels på ungdomstrinnet er samtalen med eleven om utviklingen i de enkelte fag ofte delegert til faglærerne, mens kontaktlærer har samtaler med eleven om andre forhold enn de rent faglige. Skolenes praksis varierer forøvrig mye på dette området. Det gjelder også hvor hyppig slike samtaler blir gjennomført.

Elevsamtalen er satt på dagsordenen i nasjonale satsninger for å utvikle en bedre vurderingspraksis i norsk skole. Dette føyer seg inn i en internasjonal trend de siste 10-15 årene som kan sammenfattes i målet om at vurdering av elevens arbeid og innsats skal fremme elevens læring. Et omfattende utviklingsarbeid er gjennomført i regi av Utdanningsdirektoratets satsing «Vurdering for læring» 2010-2014, som ble videreført i perioden 2014-2017 (Utdanningsdirektoratet 2015). En av de internasjonale inspirasjonskildene har vært et arbeid med den talende tittelen The power of feedback (Hattie \& Timperley 2007). Man ønsker å dreie fokus bort fra ensidig vektlegging på vurdering av elevenes resultater og over til vurdering som fremmer læring.

Formålet med denne artikkelen er å belyse elevsamtalens muligheter og begrensninger i videregående skole med basis i studier av elevers erfaringer. Forskningsspørsmålene er: Hva er gode elevsamtaler, og hva kjennetegner mindre gode samtaler mellom lærer og elev, slik 
elever opplever det? Hvordan kan samtalene eventuelt forbedres og bli mer nyttige, sett fra elevers perspektiv?

Artikkelen bygger på erfaringsmateriale fra elever i avgangsklasser i videregående skole. Sentrale kjennetegn ved det empiriske dialogbegrepet utgjør en ramme for forståelse av erfaringene.

\section{Sentrale kjennetegn ved enhver dialog - et empirisk dialogbegrep}

'Dialog' er et begrep med lange tradisjoner og ulike teoretiske tilnærminger. Det er et verdiladet begrep som ofte brukes normativt. Idealet - en «ekte» dialog - preges av respekt for hverandres synspunkter og situasjon, dialogen er åpen, «tvangsfri» og forståelsesorientert (Habermas 1981/1997). Dialog oppfattes som et ideal det er verdt å streve for. Dens motsetning, eller «bakside», karakteriseres av blant annet autoritær, dominerende eller dogmatisk væremåte og manglende vilje eller evne til å lytte til (den) andre. Samtaler som domineres av den ene av partene, betegnes gjerne som monologiske. Som tilfellet er med mange slike motsetninger, representerer dette en forenkling som kan komme til å skygge for spenninger, skjevheter og andre problemer som kan ligge både i konteksten som dialoger utspilles i, og implisitt i selve dialogen (Gurevitch 2000; Ravn 2004; Lefstein 2006).

Elevsamtaler har kanskje begrensede muligheter til å oppnå idealet om en «ekte» dialog sett i lys av ideelle krav som nevnt ovenfor. Det betyr ikke at slike samtaler nødvendigvis er «monologiske» eller dårlige dialoger. Det har vært påpekt, blant andre av Lefstein (2006), at dialog, forstått som den «rene», «ekte» dialogen, er tilnærmet umulig i skolen, på grunn av strukturelle trekk, tradisjoner og roller. Norske forskere synes mer optimistiske på dialogens - og elevsamtalens - vegne (for eksempel Limstrand 2006; Tangen 2010; Sjøbakken 2012) (se nedenfor).

For å forstå elev-lærer-dialogens muligheter og begrensninger i skolen trenger vi blant annet kunnskap om elevers og læreres erfaringer og perspektiver. Det er derfor det beskrivende eller empiriske dialogbegrepet som ligger til grunn for denne studien. Dialog kan her defineres som et direkte møte, ansikt-til-ansikt, mellom to (eller flere) deltakere som interagerer ved hjelp av språk (verbalt og nonverbalt) (Dysthe 2001; Linell 2009). Normative aspekter ved dialogen vil likevel ha stor plass ettersom vi er interessert $\mathrm{i}$ hva elevene opplever som henholdsvis positivt og negativ ved elevsamtalene. Det er med andre ord samtalenes kvalitet(er) sett fra elevenes perspektiv («nedenfra») studien dreier seg om. 
Forskjellige teorier om dialog har til felles at en dialog representerer 1) et kommunikasjonsmønster, 2) en (eller flere) relasjon(er), 3) et innhold, og 4) en måte å lare på (Lefstein 2006). Disse dimensjonene er til stede i enhver dialog, uansett hvor «god» eller «dårlig» den er. ${ }^{\mathrm{i}}$ De fire dimensjonene ved dialogen utgjør hver for seg selvstendige områder for analyse og kunnskapsutvikling. For å forstå elevers erfaringer er det likevel nødvendig å se de ulike dimensjonene i sammenheng og rette søkelyset mot den gjensidige avhengigheten mellom dem, det vil si mot dynamikken i dialogen.

\section{Forskning og utviklingsarbeid om elevsamtaler}

Et grunntema i forskning og utviklingsarbeid og elevsamtalen er naturlig nok læring. Limstrand (2006) ser elevsamtalen som kilde til danning og vekst. Elevsamtaler som læringsarena er hovedtemaet også hos Theie (2017), som finner at dialogiske arbeidsmåter stimulerer til økt elevdeltakelse, og hos Lassen og Breilid (2011), som peker på at elevsamtaler kan fungere som verktøy for selvutvikling og læring.

I en studie av kontaktlærerarbeid i videregående skole fant Ertsås (2011) at kontaktlærerne så elevsamtalen som et viktig redskap for tett oppfølging av hver enkelt elev. Tangen (2010) fant at kontaktlæreres viktigste utbytte av elevsamtaler var at de ble bedre kjent med eleven, at samtalene ga bedre grunnlag for oppfølging og tilrettelegging. Noen få påpekte at det var nyttig å få tilbakemelding om egen undervisning. Når det gjaldt utbyttet for elevene, trodde lærerne det var viktig å bli sett og hørt, å møte tillit og respekt og å $f a ̊$ tilbakemelding og veiledning. Elevsamtaler fører også til at elevene får bedre tilpasset undervisning, mente disse lærerne.

Basert på data fra Elevundersøkelsen rettet Viddal (2007) søkelyset mot tilbakemeldingsdiskurser i elevsamtalen. Dialogisk tilbakemelding innebærer her at eleven blir «sett», at den berører elevens erfaringsverden, slik at eleven kjenner seg igjen, og at læreren inkluderer både elevens og sitt eget perspektiv, og forventer mestring. Monologisk tilbakemelding kjennetegnes ved et ensidig lærerperspektiv, tilbakemeldingen gis som en «gave» og dreier seg ensidig om elevens prestasjoner, ofte med fokus på gapet mellom faktisk og ønsket resultat. Viddal fant at elever som klarte seg bra i skolen og som ikke hadde spesielle problemer faglig eller atferdsmessig, jevnt over fikk dialogiske tilbakemeldinger. Elever som var lite motivert og som slet med ulike vansker, fikk derimot oftest monologiske tilbakemeldinger. Sørensen, Theie, Lassen og Breilid (2011) fant at elever med selvrapportert 
innagerende eller utagerende atferd i ungdomsskolen vurderte kvaliteten og nytten av elevsamtaler signifikant dårligere enn elever uten slike risikofaktorer.

\section{Metode og materiale - elevenes egne ord}

I tråd med formålet for denne studien har elevene satt egne ord på sine erfaringer med og oppfatninger om elevsamtalene de har hatt. Datamaterialet består av skriftlige svar på åpne spørsmål. 76 elever (36 jenter og 40 gutter) i tre avgangsklasser (Vg3) i studieforberedende utdanningsprogram ved tre ulike skoler i to fylker deltok. Alle spørsmålene er besvart av alle eller nesten alle elevene. Lengden på svarene på hvert enkelt spørsmål varierer fra noen få stikkord til tre-fire linjer.

I sin beskrivelse og vurdering av erfaringer elevsamtaler vil eleven som regel «emphasize what people remember as significant», for å låne et uttrykk fra en dansk studie av elevers minner om egen skolegang (Tanggaard \& Nielsen 2011, s. 74).

I den tematiske analysen har det vært viktig så langt som mulig å benytte elevenes egne ord og uttrykk. ${ }^{\text {ii }}$ Målet har vært å få fram variasjonen og det kvalitative innholdet i elevenes erfaringer. I siste runde i analysen ble erfaringstemaene tolket i lys av de fire dimensjonene som kjennetegner enhver dialog (se ovenfor). I materialet er det imidlertid så nær sammenheng mellom relasjons- og kommunikasjonsdimensjonen at vi har valgt å slå sammen disse i presentasjonen av resultatene nedenfor. Den tredje dimensjonen, innholdet i dialogen, utgjør den andre hovedbolken i resultatpresentasjonen. Når det gjelder den fjerde dialogdimensjonen, læring, finnes ordet læring/å lære bare unntaksvis i datamaterialet, men elevene forteller mye om hva de får ut av samtalene. Slike utsagn er i elevenes beretninger knyttet til både relasjonen til læreren, kommunikasjonen og til innholdet.

\section{Elevers erfaringer med elev-lærer-relasjonen og kommunikasjonen i}

\section{samtalene}

A bli kjent med laereren gjennom elevsamtalen er noe av det som fremheves som positivt eller kanskje viktigere: at læreren blir bedre kjent med eleven. Det «ble mest snakk om hvordan jeg har det som person og på skolen, for å bli litt kjent (...). Fint å prate med læreren slik at hun også får et inntrykk av meg utenom skolesammenheng», heter det. Et annet moment er at læreren får «vite hvilke mål jeg har». «Vi snakket mye om fritid, hvordan person jeg er, jobb, ferier osv. for å få litt bedre forhold. Den var ikke så nyttig faglig, men 
sosialt», skriver ei jente.

Larere som bryr seg og som lytter til eleven, framstår som svært positivt.

Elevene forteller om lærere som er blide, hyggelige, positive, forståelsesfulle, for å bruke noen av elevenes egne ord. Lærere som bryr seg om elevene er viktig, som for eksempel i dette utsagnet: «Kontaktlæreren min er veldig ålreit, og det virker som han oppriktig bryr seg om elevene sine.» Mange peker på at læreren har vært interessert i hvordan eleven trives, $\mathrm{i}$ klassen og ellers, og at det er positivt at lærere «prøver så godt de kan å rette opp hvis du ikke trives». Å oppleve at en blir lyttet til, og at eleven kan ta opp det en føler behov for å snakke om, fremheves som viktig. Det kan dreie seg om at «man på tomannshånd kan ta opp ting man ikke vil andre skal høre», eller at læreren «er åpen for forslag fra meg, og vil lytte til mine $\emptyset$ nsker/behov osv.».

$\AA ̊ ㇒$ ha kontaktlærer og regelmessige elevsamtaler betyr at «man har noen man kan vende seg til hvis det er noe». Et annet sted heter det: «Det er positivt bare å vite at det er noen der for oss om vi trenger det». Samtalene har videre gitt «nærmere kontakt med en som kanskje kan hjelpe deg i ubekvemme situasjoner, o.l.».

Åpenhet, fortrolighet og tillit preger gode elevsamtaler, slik elevene ser det. Det er «fint å kunne snakke med kontaktlærer uten at andre medelever er til stede». Det handler også om å få personlig oppmerksomhet fra lærer og «at kontaktlæreren forholder seg til meg selv, istedenfor hele klassen». En elev skriver: «Hvis det er noe jeg har lyst til å si, kan jeg lettere åpne meg under elevsamtalene.» At samtalene foregår under fire øyne, gir eleven mulighet til å ta opp ting som er viktige for skolegangen og «stille spørsmål du ellers ikke får mulighet til å stille».

En del elever har bare positive erfaringer og $\varnothing$ nsker ingen endringer. I slike tilfelle er det nettopp forholdet til og kommunikasjonen med læreren som framheves: «Kjemien mellom meg og min kontaktlærer er på topp! Ingen problemer». Et annet sted heter det: «Jeg har alltid hatt en god dialog med lærerne, så jeg føler ikke at noe burde vært gjort annerledes.»

I en del tilfelle er det tydelig at kommunikasjonen ikke har fungert særlig godt. På spørsmål om hva elevene eventuelt $\emptyset n s k e r$ av endringer/forbedringer, er ett av temaene at læreren $m a ̊$ lytte mer til eleven. Noen gir uttrykk for at de sliter med å kommunisere med læreren. Det kommer også til uttrykk et ønske om at læreren spurte mer. Noen sitter igjen med et фnske om at de selv hadde spurt om flere ting og «at det ikke bare var læreren som stilte spørsmålene». Elev-lærer-forholdet «er jo litt rart», skriver en elev, og det er «kanskje ikke så lett å fortelle alt om deg selv til læreren». Når en ønsker «at det ikke var så flaut å sitte der alene med 
læreren», og når det var «litt «pinlig stemning» i elevsamtalene, er det nok et uttrykk for at kommunikasjonen med læreren kan oppleves som ganske krevende.

\section{Innholdet i samtalene}

Å få faglig tilbakemelding og større klarhet i hva en må jobbe med for å forbedre sine karakterer, står sentralt. En positiv erfaring er beskrevet slik: «Jeg fikk mye informasjon angående min arbeidsinnsats og hvordan jeg lå an med karakterer og hva som måtte til for å forbedre dem». Det er ikke nødvendigvis bare eleven som kan gjøre noe for å forbedre karakterene; det gjelder også læreren: «Vi snakker om hva læreren/jeg kan gjøre for å få bedre karakterer.» En annen skriver at det har vært fint å «sette opp karaktermål i alle fag for å få en oversikt over hva jeg skal jobbe med».

Faglig tilbakemelding går ofte går hånd i hånd med andre temaer, for eksempel klassemiljøet: «Siste elevsamtale opplevde jeg som positiv. (...) Vi snakket også om hva jeg kan gjøre for å forbedre klassemiljøet.» En nyttig erfaring kan være å få respons på hvordan man som elev oppleves i timene. At elevsamtalen også gir «en mulighet til å snakke med læreren utenom pensum og skolefag», fremheves som positivt. Det er tydelig at elevsamtaler som fungerer godt for eleven, kan handle om både faglige, personlige og sosiale forhold: «Det var en positiv samtale der vi snakket om hvordan jeg gjorde det i fagene. Læreren spurte også om situasjonen hjemme (...), jobb, fritid osv.».

Larerens måte å gi feedback på - og holdningen til elevene - har åpenbart betydning for om samtalen oppleves som god og nyttig. Et eksempel: «Veiledning, følelsen av at de bryr seg om hvordan du gjør det, og ikke bare gjør jobben sin rent faglig. Hjelper til med selvutvikling.»

Veien videre etter skolegangen er noe avgangselevene har satt pris på å få snakke om. Det kan handle om at lærer og elev sammen prøver «å finne ut hva som passer meg, både sosialt og utdanningsmessig», at læreren er interessert i hva eleven «ville gjøre med livet etter videregående», eller at samtalene har «satt i gang tankeprosessen til videre utdanning».

Når det gjelder mindre gode erfaringer og ønsker om forbedringer, kommer det fram at en del av elevene savner mer konkrete tilbakemeldinger. Læreren burde ha samlet mer informasjon på forhånd fra lærerne i de andre fagene, heter det. I mange tilfelle har faglærere korte 
fagsamtaler med hver elev før kontaktlærerne har elevsamtaler med «sine» elever. Men dette kan også by på problemer: «Samtalen er, for det meste, bortkastet tid. Alle tilbakemeldinger har du allerede fătt en gang før [i fagsamtalene]. Begge snakker greit, men det er ingenting konkret å gjøre.» Det påpekes at samtalen kunne være mer konstruktiv «i forhold til fag der man ikke har utnyttet potensialet sitt. Det kan bli litt mye 'ja, så flink du er' og lite konkret».

Et annet tema som går igjen, er at samtalene burde handle mer om undervisningen. Det dreier seg blant annet om å kunne gi tilbakemelding om/til lærere. Samtalene burde ta for seg «grundigere spørsmål om undervisning», heter det. En elev skriver at alt hun sier i elevsamtaler, blir tatt alvorlig, og at hun stoler på at det hun sier, ikke går videre om hun ikke $\emptyset$ nsker det. Hun fortsetter: «Jeg ville kanskje ønsket at det kunne være mulig å gi tilbakemeldinger på enkelte lærere som jeg ønsket skulle forandre læremåter.». Utsagnet indikerer kanskje at det kan være vanskelig for en elev å ta opp problemer knyttet til undervisningen - selv der hvor kommunikasjonen er god og tillitsfull. Det etterlyses for $\varnothing$ vrig mer ærlighet i elevsamtalene. En elev utdyper dette med at man må tåle konstruktiv kritikk begge veier.

Videre kommer det fram at samtalene kan oppleves som overfladiske og repeterende. Det hadde vært bedre at «man går litt dypere inn på ting, ikke bare kjapt gjennom alle spørsmålene». Et ønske er at «oppskriften på utspørringen» blir endret. Det ser ut til at malen for samtalene kan bidra til at de oppleves som formelle og overflatiske: «Det blir jo alltid som å fylle ut et skjema: veldig formelt. Man hopper fra spørsmål til spørsmål, og svarene fra meg som elev blir sjelden godt grunnlagt. Det er lett å svare "halvveis" om hvordan skolen er, med mindre det har skjedd noe spesielt.»

Det uttrykkes en viss oppgitthet over at samtalene tar opp «de samme spørsmålene hver gang». Samtalene kan oppleves som en stadig repetisjon. «Skulle ønske at det kanskje kunne handle om noe annet enn fravær en gang i blant.»

Større engasjement fra både lærer og elev etterlyses, at samtalene «var noe man gjorde fordi man ville/trengte i motsetning til at det ble en plikt både fra elevens side, men også spesielt fra lærerens side».

\section{Diskusjon}

Som angitt innledningsvis, er det et empirisk dialogbegrep med fire sentrale kjennetegn som har dannet rammen for presentasjonen og forståelsen av elevenes erfaringer med elevsamtaler 
og deres eventuelle ønsker om forbedringer. De empiriske kjennetegnene eller dimensjonene ved dialoger er: kommunikasjonsmønster, relasjon(er), innholdet i dialogen samt læring.

Vi har sett at det er stor variasjon i elevenes svar, samtidig som noen typer av erfaringer og oppfatninger går igjen. De fleste avgangselevene beskrev noe positivt de hadde opplevd ved elevsamtalene. Samtidig ga over halvparten uttrykk for ønsker om endringer. Relasjonen til laereren framstår som et omdreiningspunkt i uttalelsene; det kjennetegner både positive og negative erfaringer. Når det gjelder erfaringer med kommunikasjonen mellom læreren og eleven, er de fleste elevene opptatt av lærerens måte å kommunisere på, men en del av dem reflekterer også over sin egen rolle i samtalen. Innholdet i samtalene er gjerne styrt av en mal (et skjema) med faste spørsmål. Det er likevel store variasjoner i hva det snakkes om. Noen opplever at de kan snakke med læreren nær sagt om hva som helst. Andre opplever elevsamtalene som overflatiske repetisjoner som de får lite eller ingenting ut av. Forholdet til læreren spiller åpenbart en betydelig rolle både for samtalens innhold og for hva den gir av laering.

De ulike dimensjonene ved dialogen ser ut til å henge nøye sammen. $\AA$ erfare at læreren bryr seg om eleven, viser tillit (relasjonen), er interessert og lyttende (kommunikasjonen), gjør det lettere for eleven å ta opp ting hun/han ønsker å snakke eller spørre om (innhold). Dermed blir det også lettere å ta imot lærerens tilbakemeldinger og veiledning, og åpenheten og tilliten gjør at samtalen kan bli en god læringsarena for begge parter (en måte å lære på).

Elevenes erfaringer sier noe om hvilke muligheter som ligger i samtalen når det gjelder å skape gode relasjoner, styrke elevenes motivasjon og gi konkret veiledning for videre læring. Resultatene indikerer også at samtalen kan bidra til å skape større trygghet, og dermed en bedre skolehverdag for eleven, blant annet ved at elevene vet at det er noen der for dem om de trenger det. I slike tilfelle kan relasjonen mellom elev og lærer karakteriseres som en allianse (Tangen 2019). Selv om det er godt dokumentert at forholdet mellom lærer og elev er viktig for elevens motivasjon og innsats, og dermed for elevens læring, synes kunnskapen om elevers erfaringer med og perspektiver på dette forholdet fortsatt mangelfull (Federici \& Skaalvik 2013). Det er tankevekkende i lys av at læreren kan sies å være en «relasjonsarbeider» (Mausethagen \& Kostø1 2010).

En side ved elevenes mindre positive erfaringer er at samtalesituasjonen kan oppleves som «litt rar». Dette handler kanskje om at rollene de to samtalepartene har - sett fra elevens perspektiv - kan representere en utfordring for samtaler på to-mannshånd. Det kan rett og slett oppleves som flaut eller pinlig å sitte der alene med læreren. Siden det er læreren som i 
kraft av sin rolle har hovedansvaret for relasjonen til og kommunikasjonen med eleven, kan kanskje slike eleverfaringer i en del tilfelle tilskrives noe mangelfull kompetanse hos læreren.

En del elever peker på at læreren må lytte mer i elevsamtaler. Samtidig ser vi at noen elever, i etterpåklokskapens lys, mener at de selv kunne ha vært mer aktive og tatt opp ting som de ønsket å snakke eller spørre om. De ser seg dermed som medansvarlige for så vel kommunikasjonen som for innholdet i samtalen. Men det kan uansett være vanskelig å ta opp ting med læreren som det ikke har vært vanlig å snakke om tidligere, eller som en tror ligger utenfor rammen for samtalen.

Et sentralt tema i samtalene er elevens faglige resultater og muligheter for å forbedre disse. Erfaringer her er varierende. Noen har opplevd tilbakemeldingene som nyttige for videre arbeid, andre har savnet mer konkrete tilbakemeldinger. Dette samsvarer med resultater som kom fram i prosjektet Forskning på individuell vurdering i skolen (FIVIS), som studerte hvordan vurderingspraksis i norske skoler utvikler seg. Her uttrykte elevene at noen lærere var konstruktive og ga grundig veiledning, mens andre lærere ga korte og temmelig intetsigende kommentarer (Sandvik \& Buland, 2014, s. 1112). For å kunne gi læringsfremmende tilbakemeldinger, fremheves ofte betydningen av det relasjonelle, at læreren må kunne kommunisere med alle på deres egne premisser, påpeker disse forskerne.

I sin forskning omkring formativ evaluering søker den danske forskeren Christensen (2016) å bygge opp det han kaller «refleksive rum» gjennom lærer-elev-samtaler i undervisningen. En del av de gode samtalene det fortelles om i vår studie, kan kanskje sies å inneholde slike refleksive rom. At eleven deltar aktivt, er iallfall en forutsetning for at «feedback dialogues» skal stimulere til refleksjon (Van der Schaaf, Baartman, Prins, Oosterbaan \& Schaap 2011).

Et tydelig trekk i vår studie er at elevene savner eller synes det blir snakket for lite eller for overfladisk om enkelte temaer. Det kan også være at samtalen helt eller delvis oppleves som overflødig, irrelevant eller unødig formalistisk eller «skjematisk». Samtalene kan oppleves som unyttige repetisjoner, og læringsresultatet blir dermed negativt.

I vår studie kommer det fram et tydelig ønske hos elever om bedre mulighet til å snakke om undervisningen og hva som kan gjøres for at den skal fungere bedre. Et sideblikk på en annen type samtaler i skolen kan være tankevekkende i denne sammenheng: kollegasamtaler/-veiledning. Å utveksle erfaringer og lære av hverandre med sikte på å utvikle egen undervisning er et mål for slike samtaler. Junge (2012) gjennomgikk tidligere undersøkelser av kollegasamtaler om elevers atferd i undervisningen. Hun fant at kollegasamtalene sjelden drøfter mulige sammenhenger mellom elevatferden og 
undervisningen; samtalene preges mer av beskrivelser av eleven og hjemmeforhold. Junges egen empiriske studie av kollegasamtaler viser det samme bildet. Hun konkluderer med at dette begrenser lærernes utforsking av erfaringer og utvikling av ny kunnskap. På tilsvarende måte vil vi påpeke at dersom elevenes opplevelse av undervisningen og skolens tilrettelegging sjelden er et tema i elevsamtaler, utnyttes ikke samtalens muligheter som grunnlag for å justere og berike opplæringen. Elevenes erfaringer indikerer at bare et lite mindretall av lærere bruker den muligheten elevsamtalen gir til å få tilbakemelding på og ideer til egen undervisning. Dette samsvarer både med en studie av læreres erfaringer (Tangen 2010) og elevers erfaringer (Tangen \& Theie 2014), samt med resultatene fra FIVIS-prosjektet, som viste at lærere $i$ liten grad benytter tilbakemeldinger fra elever i videre arbeid med egen undervisning (Sandvik \& Buland 2014). I likhet med disse forskerne ser vi et klart forbedringspotensial når det gjelder å utvikle elevsamtalen som et ledd i utviklingen av tilpasset opplæring.

Når samtalene fungerer godt, kan de gi et viktig bidrag til positiv læring og utvikling for så vel eleven som for læreren. På den annen side kan elevsamtaler også bidra til å bekrefte en dårlig relasjon mellom lærer og elev. Det blir derfor særlig viktig å være oppmerksom på de elevene som opplever lite eller ikke noe utbytte av elevsamtalene, og som kanskje sitter igjen med negative erfaringer.

Det er på sin plass å minne om at elevsamtalene ikke foregår i et vakuum. Konteksten de inngår i, kan representere så vel betydelige utfordringer som muligheter. Stikkord er blant annet skoleledelse, lærerkompetanse og -samarbeid, tidsressurser, lokaler, organisering og skolekultur. Våre data gir imidlertid ikke grunnlag for å ta opp slike spørsmål.

Uavhengig av konteksten som samtalene foregår i, gir elevenes erfaringer med samtalene viktig kunnskap om hvordan elevsamtaler kan forbedres. Det gjelder muligheten til å skape et godt elev-lærer-forhold, og til å styrke engasjement, refleksjon og positiv læring. Med grunnlag i forskning i svenske skoler understreker Torkildsen og Erickson (2016) også viktigheten av å ta elevenes stemme i betraktning for å kunne skape vurderingspraksiser som gir bedre læring.

\section{Konklusjon}

Formålet med artikkelen har vært å belyse elevsamtalens muligheter og begrensninger med basis i studier av elevers erfaringer og ønsker om forbedringer. 
En rimelig konklusjon synes å være at elevsamtaler i praksis kan bidra til trygghet og trivsel og gi vesentlige og positive læringsgevinster for elevene. Det ser ut til å være relasjonen til læreren som er mest avgjørende for om samtalene oppleves som gode eller mindre gode. Dette harmonerer med tidligere forskning som viser at elev-lærer-relasjonen er svært viktig for elevenes innsats og læring. Et godt forhold til læreren og god kommunikasjon betyr imidlertid ikke at elever ikke ønsker eller ser muligheter for at samtalene kan bli bedre eller mer nyttige. Elevenes erfaringer i denne studien tyder på at det finnes et betydelig forbedringspotensial. Et praktisk og konkret forhold gjelder malene eller skjemaene som benyttes for gjennomføring av elevsamtaler. Det kan se ut til at når slike maler følges slavisk, tenderer samtalene til å bli skjematiske og repeterende. Dette kan gi mindre rom for eleven til å ta opp egne bekymringer eller ønsker. Kanskje er dette noe av forklaringen på en del elevers opplevelse av at læreren ikke lytter til dem. For enkelte elever ser det ut til at samtalene gir et direkte negativt læringsresultat. Da kan vi, med uttrykk hentet fra Möllås (2009), tale om læring som bryter ned i stedet for å bygge opp.

Skulle vi driste oss til, ut fra vårt materiale, å peke på noe som trolig kan bidra til bedre utnytting av elevsamtalens potensial, er stikkordet større bevissthet om muligheten for gjensidig læring. I de seinere år er det satset mye på å utvikle læringsfremmende vurderingspraksis i norsk skole. Elevsamtalen er et viktig redskap i denne sammenheng. Skal samtalen bidra til positiv innsats og læring for eleven, er det imidlertid viktig at den også gir læring for læreren, i form av blant annet innsikt i elevens situasjon og forhold som er av betydning for hans eller hennes læring. Som vi har sett, ønsker elevene også mulighet til å ta opp forhold som er knyttet til undervisningen Sett fra elevenes perspektiv kan det se ut til at gjensidig læring i noen tilfeller forutsetter større åpenhet, vilje og/eller kompetanse hos læreren til å lytte seg inn i elevens erfaringsverden og framtidshorisont. Men de største begrensningene som ligger i elevsamtalen, er sannsynligvis knyttet til det å gjennomgående ta konsekvensene av den kunnskapen som slike samtaler med elevene kan gi. Slik vi ser det, ville det kreve at elevenes stemmer i skolen får betydelig mer innflytelse, blant annet når det gjelder innhold og arbeidsmåter. Kanskje er det først og fremst her den idealistiske oppfatningen av dialogbegrepet kolliderer med etablerte roller og tradisjoner, systemer og strukturelle forhold. 


\section{Litteratur}

Christensen, Torben Spanget (2016). Refleksive rum og formativ evaluering i undervisning. Cepra-Striben, 8(1), s. 42-55. DOI: 10.17896/UCN.cepra.n08.161

Dyste, Olga (2001). Om samanhengen mellom dialog, samspel og læring. I Olga Dysthe (red.). Dialog, samspel og laering. Oslo: Abstrakt forlag.

Ertsås, Turid I. (2011). Kontaktlaererarbeid i videregående skole. En kvaliativ studie av kontaklaerers utvikling av praksiskunnskap. Doktorgradsavhandling, Pedagogisk institutt, NTNU, Trondheim.

Federici, Roger Andre \& Skaalvik, Einar M. (2013). Lærer-elev-relasjonen - betydning for elevenes motivasjon og læring. Bedre Skole (1), s. 58-64.

Gurevitch, Zali (2000). Plurality in dialogue: A comment on Bakhtin. Sociology, 34(2), s. 243-63.

Habermas, Jürgen (1981/1997). Teorien om den kommunikative handlen. Aalborg: Aalborg Universitetsforlag. [Dansk oversettelse etter originalutg. Theorie des kommunikativen Handles. Bd. 1-2. Suhrkamp Verlag 1981.]

Hattie, John \& Timperley, Helen (2007). The power of feedback. Review of Educational Research, 77(1), s. $81-112$.

Junge, June (2012). Kjennetegn ved læreres kollegasamtaler, og betydningen av disse for læringspotensialet i samtalene. Norsk Pedagogisk Tidsskrift, 96(5), s. 373-386.

Kunnskapsdepartementet (2006). Forskrift til opplaringslova. Oslo: Kunnskapsdepartementet

Lassen, Liv \& Breilid, Nils (2011). Elevsamtaler som veiledningsverktøy i arbeidet med elevers selvutvikling og læringsutbytte i skolen. I Kaare Skagen (red.). Kunnskap og handling i pedagogisk veiledning (s. 93-114). Bergen: Fagbokforlaget.

Lefstein, Adam (2006). Dialog in schools: Towards a pragmatic approach. Working papers in urban literacies. London: King's College.

Limstrand, Kirsten M. (2006). Elevsamtalen. En kilde til danning og vekst. Bergen: Fagbokforlaget.

Limstrand, Kirsten M. (2011). Elevsamtalen for tilpasset opplæring. I Halvor Bjørnsrud \& Sven Nilsen (red.). Laererarbeid for tilpasset opplaring: tilrettelegging for laering og utvikling. Oslo: Gyldendal Akademisk.

Linell, Per (2009). Rethinking language, mind, and world dialogically. Interactional and 
contextual theories of human sense-making. Charlotte, NC: Information Age Publishing.

Mausethagen, Sølvi \& Kostøl, Anne (2010). Det relasjonelle aspektet ved lærerrollen. Norsk Pedagogisk Tidsskrift, 94(3), s. 231-243.

Möllås, Gunvie (2009). «Detta ideliga mötande». En studie av hur kommunkation och samspel konstituerar gymnasieelevers skolpraktik. Doktorgradsavhandling, Högskolan för kommunikation och lärande, Jönköping.

Ravn, Birte (2004). Samtale og makt. I Per Arneberg, Jan Harald Kjærre \& Bjørn Overland (red). Samtalen i skolen. Oslo: N.W. Damm \& Søn.

Sandvik, Lise Vikan \& Buland, Trond (red.)(2014). Vurdering i skolen. Utvikling av kompetanse og fellesskap (Sluttrapport fra prosjektet Forsking på individuell vurdering i skolen (FIVIS)). Trondheim: NTNU Program for lærerutdanning \& SINTEF.

Sjøbakken, Ola J. (2012). Elevsamtalen som jevnlig dialog i et aksjonsforskningsperspektiv. Doktorgradsavhandling, Pedagogisk forskningsinstitutt, Universitetet i Oslo/Unipub forlag.

Sørensen, Peer M., Theie, Steinar, Lassen, Liv \& Breilid, Nils (2011). Ungdomsskoleelevers vurdering av nytten og kvaliteten på planlagte elevsamtaler, med fokus på elever i risiko. Spesialpedagogikk, 76(1), s. 74-86.

Tangen, Reidun. (2010). Elevsamtalens betydning for tilpasset opplæring. En undersøkelse blant kontaktlærere i videregående skole. I Jorun Buli-Holmberg \& Sven Nilsen (red.). Kvalitetsutvikling av tilpasset opplaring. Om forbedring av opplaringen for barn, unge og voksne med sarskilte behov. Oslo: Universitetsforlaget.

Tangen, Reidun (2019). Elevers skolelivskvalitet. I Edvard Befring, Kari-Anne B. Næss \& Reidun Tangen (red.). Spesialpedagogikk (6. utg.). Oslo: Cappelen Damm Akademisk

Tangen, Reidun \& Theie, Steinar (2014). Elevsamtaler i videregående skole - hvordan husker elever dem i ettertid? Psykologi i kommunen, 49(2), s. 25-37.

Tanggard, Lene \& Nielsen, Klaus (2013). School Memories Situating School. Scandinavian Journal of Educational Research, 57(1), s. 71-88. DOI: 10.1080/00313831.2011.621974 (http://dx.doi.org/10.1080/00313831.2011.621974)

Theie, Steinar (2017). Elev-lærer-samtaler som læringsarenaer. I Sven Nilsen (red.). Inkluderingog mangfold - sett i spesialpedagogisk perspektiv. Oslo: Universitetsforlaget. 
Torkildsen, Lisbeth Gyllander \& Erickson, Gudrun (2016). 'If they'd written more...' - On students' perceptions of assessment and assessment practices. Education Inquiry, 7(2). DOI: $\underline{\text { https://doi.org/10.3402/edui.v7.27416 Actions }}$

Utdanningsdirektoratet (2015). Grunnlagsdokument. Videreføring av satsingen

Vurdering for laering 2014-2017. Hentet fra

https://www.udir.no/globalassets/filer/vurdering/vfl/andre-

dokumenter/felles/grunnlagsdokument-2014-2017.pdf.

Van der Schaaf, Marieke, Baartman, Liesbeth, Prins, Frans, Oosterbaan, Anne \& Schaap,

Harmen (2011). Feedback Dialogues That Stimulate Students' Reflective Thinking.

Scandinavian Journal of Educational Research, 57(3), s. 227-245. DOI:

10.1080/00313831.2011.628693 (http://doi.org/10.1080/00313831.2011.628693)

Viddal, Linda M. (2007). Tilbakemeldingsdiskurser i elevsamtalen. I Sverre Tveit (red.).

Elevvurdering i skolen. Grunnlag for kulturendring. Oslo: Universitetsforlaget.

\section{Noter}

\footnotetext{
${ }^{\mathrm{i}}$ Lefstein (2006) omtaler i tillegg til de fire nevnte dimensjoner også en femte: dialog som en epistemologisk posisjon, som han mener impliserer blant annet ydmykhet og erkjennelse av iboende begrensninger i egen viten, $\mathrm{og}$ åpenhet overfor andre.

ii Dataprogrammet NVivo10 ble brukt i analysearbeidet.
} 